\title{
The Privilege of The Indonesia Investment Authority in Indonesia Omnibus Law on Job Creation*
}

\author{
Putu Samawati ${ }^{1}$, Shinta Paramita Sari ${ }^{2}$ \\ Law Faculty of Sriwijaya University, Palembang Indonesia \\ doi 10.15408/jch.v9i1.20164
}

\begin{abstract}
Economic globalization has an impact on the dynamics of adjusting the legal rules established in Indonesia. One of them is the legal unification format called the Omnibus Law on Job Creation. The Omnibus Law on Job Creation collects laws related to development and investment. The new thing in this law is the formation of a new institution called the Sovereign Wealth Fund. Various privileges are given to an institution called the Indonesia Investment Authority (IIA), ranging from not being held accountable for a loss to being audited only by a public accountant. This article discusses how laws and regulations build the construction of the Sovereign Wealth Fund Indonesia. The main problem that was analyzed is how the position of the Sovereign Wealth Fund in the structure of the Indonesian state institutions, besides that, it also discusses the issue of the authority and responsibility of the Sovereign Wealth Fund as well as the privileges provided by laws and regulations. All of these issues be the scope of discussion that provides an overview of Indonesia's Sovereign Wealth Fund. The discussion was conducted using a normative juridical method through qualitative analysis using a statutory approach and legal philosophy approach. The inductive conclusion is expected to provide input in strengthening IIA construction so as not to get demands for discriminatory treatment by other state institutions, and the goal of being established by the IIA to accelerate national economic development can be realized.

Keywords: Privilege, Indonesia Investment Authority, Omnibus Law on Job Creation, Sovereign Wealth Fund.
\end{abstract}

${ }^{*}$ Received: February 13, 2021, revised: February 17, 2021, accepted: March 15, 2021, Published: April 1, 2021.

${ }^{1}$ Putu Samawati is a Candidate of Doctor in Law, Associate Professor of Law Faculty of Sriwijaya University Palembang-Indonesia, ORCID: https://orcid.org/0000-0001-6088-4934

${ }^{2}$ Shinta Paramita Sari is a Doctor in Law, Associate Professor of Law Faculty of Sriwijaya University Palembang-Indonesia, ORCID: https://orcid.org/0000-000. 


\title{
Abstrak
}

\section{Keistimewaan Indonesia Investment Authority Dalam Omnibus Law Cipta Kerja Indonesia}

Globalisasi ekonomi berdampak pada dinamika penyesuaian aturan-aturan hukum yang ditetapkan di Indonesia. Salah satunya adalah format penyatuan hukum yang diberi nama Omnibus Law Cipta Kerja. Omnibus Cipta Kerja ini menghimpun undang-undang yang berkaitan dengan pembangunan dan investasi. Hal baru yang diatur dalam undang-undang ini adalah pembentukan lembaga baru yang diberi nama Soverign Wealth Fund. Berbagai keistimewaan diberikan kepada lembaga yang diberi nama Indonesia Investment Authority (IIA), mulai dari tidak dapat dimintakan pertanggung jawaban apabila mengalami kerugian hingga hanya dapat diaudit oleh akuntan publik. Artikel ini membahas mengenai bagaimana peraturan perundang-undangan membangun konstruksi Soverign Wealth Fund Indonesia. Permasalahan utama yang dianalisis adalah bagaimana kedudukan Soverign Wealth Fund dalam struktur lembaga negara Indonesia, selain itu juga dibahas mengenai persoalan kewenangan dan tanggung jawab Soverign Wealth Fund serta keistimewaan-keistimewaan yang diberikan oleh peraturan perundang-undangan. Kesemuaan permasalahan ini menjadi ruang lingkup pembahasan yang akan memberikan gambaran mengenai Soverign Wealth Fund Indonesia. Pembahasan dilakukan dengan metode yuridis normatif melalui analisis secara kualitatif yang menggunakan pendekatan perundangundangan dan pendekatan filsafat hukum. Kesimpulan secara induktif diharapkan dapat memberikan masukan dalam menguatkan konstruksi IIA agar tidak mendapatkan tuntutan perlakuan diskriminasi oleh lembaga negara lain, dan tujuan didirikan IIA untuk percepatan pembangunan perekonomian nasional dapat terealisasi.

Kata Kunci: Keiistimewaan, Indonesian Investment Authority, Omnibu Law Cipta Kerja, Lembaga Pengelola Investasi

\section{Привилегии инвестиционного управления Индонезии по Закону Омнибуса о создании рабочих мест в Индонезии}

\begin{abstract}
Аннотация
Экономическая глобализация влияет на динамику регулировки правовых норм, установленных в Индонезии. Одна из них - это юридический формат унификации, который называется Законом Омнибуса о создании рабочих мест. Закон Омнибуса о создании рабочих мест включает в себя законы, связанные с развитием и инвестициями. Новым в этом законе является создание нового учреждения под названием Фонд Национального Благосостояния (Sovereign Wealth Fund). Учреждению, называемому Инвестиционным Управлением Индонезии (IIA), предоставляются различные привилегии, от отсутствия ответственности за убытки до проверки только государственным аудитором. В этой статье обсуждается, как законы и нормативные акты строят структуру Фонда Суверенного Благосостояния Индонезии. Основная проблема, которая была проанализирована, заключается в том, какое положение у Фонда Суверенного Благосостояния в структуре государственных учреждений Индонезии, помимо этого, также обсуждается вопрос о полномочиях и ответственности Фонда Суверенного Благосостояния, а также о привилегиях, обеспеченных законами и регулированиями. Все эти вопросы являются предметом обсуждения, который дает обзор Фонда Суверенного Благосостояния Индонезии. Обсуждение проводилось с использованием нормативно- правового метода посредством качественного анализа с использованием статутного подхода и философскоправового подхода. Предполагается, что индуктивный вывод внесет вклад в укрепление построения IIA, чтобы не получить требований о дискриминационном обращении со стороны других государственных учреждений, и цель, поставленная IIA для ускорения национального экономического развития, может быть реализована.

Ключевые Слова: Привилегия, Инвестиционное Управление Индонезии, Закон Омнибуса о создании рабочих мест, Фонд национального благосостояния
\end{abstract}




\section{A. INTRODUCTION}

The Job Creation Bill (Omnibus Law on Job Creation) was passed into law by the House of Representatives (Dewan Perwakilan Rakyat Indonesia) on October 5, 2020 (Hamzah, 2020) was subsequently ratified by the President on November 2, 2020, in State Gazette No. 245 under the name Law No.11 of 2020 concerning Job Creation hereinafter referred to as Omnibus Law on Job Creation. The substance of the Omnibus Law on Job Creation is amending, deleting and cancelling 79 laws relating to development and investment, which are scattered in 186 articles. 11 clusters are discussed in the Omnibus Law on Job Creation. One of them is the investment cluster and government projects. In this cluster, there is a discussion about the formation of a Sovereign Wealth Fund (SWF) which will manage funds from investors who will be placed in Indonesia. SWF can carry out investments directly or indirectly and is even allowed to collaborate with other parties (Lingga, 2020). The existence of this SWF is a government strategy to attract investors to be willing to invest their funds in Indonesia. The purpose is that Indonesia's economic growth will increase or at least be able to catch up with the level of economic growth with neighbouring countries.

Indonesia's economic growth rate is still far behind Singapore and Malaysia, which are Indonesia's closest neighbours. The slow rate of economic growth is influenced by the value of the level of competition in business activities carried out by a country, including the level of investment competition. Based on the global competition index, Indonesia is still in 50th rank, while Malaysia is in 27th rank and Singapore is in the top rank.

\section{Tabel 1}

Global Competitiveness Index (GCI) Ranking

\begin{tabular}{ccccc}
\hline & 2019 & & \multicolumn{2}{c}{ Diff. From 2018 } \\
\hline Rank & Country & Score & Rank & Score \\
\hline 1 & Singapore & 84.8 & +1 & +1.3 \\
27 & Malaysia & 74.6 & -2 & +0.2 \\
40 & Thailand & 68.1 & -2 & +0.6 \\
$\mathbf{5 0}$ & Indonesia & $\mathbf{6 4 . 6}$ & -5 & $-\mathbf{0 . 3}$ \\
64 & The Philippines & 61.9 & -8 & -0.3 \\
67 & Vietnam & 61.5 & +10 & +3.5 \\
\hline
\end{tabular}

Source: GCI 2018, World Economic Forum 
The best position achieved by Singapore is the reason for the Indonesian government to make it a role model, one of which is by establishing SWF which adopts Temasek Singapore. Temasek as a Singapore-owned investment enterprise was founded in 1974 and has reported net income until the end of March 2019 of 313 billion Singapore dollars or equivalent to IDR3,214 trillion. The amount of this value is around 1.5 times Indonesia's state revenue in the 2020 Draft State Budget. Temasek's investment in domestic companies reaches $26 \%$, while those spread across Asia reaches $40 \%$, and the remaining $34 \%$ are spread across other continental countries (Tobing, 2020). Similar conditions were carried out by Malaysia by establishing the Sovereign Wealth Fund which was named Khazanah Nasional Berhad. The institution, which was established on September 3, 1993, is domiciled under the Malaysian Ministry of Finance, whose main function is to manage all commercial assets of the Malaysian government and is the holder of the mandate of state financial assets. Currently, the total assets of Khazanah Nasional Berhad reach US \$ 29 billion, the majority of which comes from internal funds and manages around US \$ 42 billion to support many strategic infrastructure projects in Malaysia (Sulaeman, 2020).

SWF is the realization of a government investment management scheme by an institution that was initiated in 2004. Initially, government investment institutions were formed as an embodiment of the mandate of Article 41 and Article 69 of Law No.1 of 2004 concerning the State Treasury. The formation of government investment institutions begins with the establishment of a Temporary Work Unit for the Government Investment Agency based on the Decree of the Minister of Finance No. 1005/KMK.05/2006 concerning the Determination of Government Investment Bodies that apply the Public Service Agency (PSA) financial pattern. At the time of the enactment of Government Regulation No.8 of 2007 concerning Government Investment, the Government Investment Board was replaced by the Government Investment Center (GIC) through the Minister of Finance Regulation No.52/PMK.01/2007 concerning the Organization and Administration of the Government Investment Center.

The subsequent achievement of this Government Regulation was replaced by Government Regulation No.1 of 2008 concerning Government Investment and lastly amended by Government Regulation No.49 of 2011 concerning Government Investment. The strengthening of GIC is carried out by making it a non-echelon organization in the field of government investment management that is under and responsible to the minister of finance through the SecretaryGeneral of the Indonesian Ministry of Finance, based on the Regulation of the Minister of Finance No.135/PMK.01/2011 concerning Organization and Government Investment Creation Center. However, based on the Minister of 
Finance Regulation No.56/PMK.01/2014 concerning the Third Amendment to the Minister of Finance Regulation No.135/PMK.01/2011, implementation of the GIC organizational transformation has been postponed until it is declared ready. Then were issued Law No.3 of 2015 on State Revenue Budget-change of 2015. In Article 23A paragraph (1) it is stated that all Government Investments that are in the Government Investment Center are transferred to state equity investments of the amount is IDR18.356 Trillion transferred to PT. Sarana Multi Infrastructure. This transfer of funds has an impact on GIC, which has been managing infrastructure funds into a vacuum. The vacuum of GIC performance has urged the government to form an institution that can managing investment in Indonesia centrally.

The existence of the Omnibus Law on Job Creation instructs the establishment of a Sovereign Wealth Fund which will increase and optimize asset value in the long term to support sustainable development (Article 156 Paragraph 2). The formation of the Sovereign Wealth Fund is expected by the government to increase the rate of the nation's economy by attracting investment funds that reach 3 times the equity or amounting to the US \$ 15 Billion or the equivalent of IDR255 Trillion (Allard, 2020). Several things are unique in the formation of the Sovereign Wealth Fund. This institution is a legal entity where the initial capital of its establishment is IDR75 Trillion, which comes from cash, state-owned asset, state receivables and state-owned shares in State-Owned Enterprises (SOEs) or limited liability companies (Article 170 paragraph (1) Omnibus Law on Job Creation). The problem is that the construction of SWF has been confused, starting from the form of its business entity which is not expressly stated as a public legal entity or a private legal entity. Another problem is that SWF capital comes from the state, but if it's lost, the SWF doesn't responsible for the loss. Another problem is the auditor for SWF which is only carried out by a public accountant. The various privilege given to SWF is interesting to discuss in this article, the point of views will open up space in forming an SWF construction that is more conducive to realization by the government.

\section{B. METHODS}

The method used in the preparation of this article is juridical normative/documentary research (Soejono and Abdurrahman, 2003, p.112), through a statute approach and legal philosophy approach (Sidharta, 2001, p.23). The data used are secondary data, which obtained through tracing primary, secondary and tertiary legal materials (Soekanto and Mamudji, 2006, p.10). After the data of the research has been collected, the next step is to 
process the data, which begins with classifying the facts, classifying the legal issues under study until finally conducting a legal analysis. An analysis is carried out by the doctrinal method through prescriptive optics, which uses a statutory approach and a legal history approach. The results of the analysis will appear a conclusion that provides a legal view of the concept of the Indonesia Investment Authority (Sunggono, 2007, p.10).

\section{RESULTS AND DISCUSSION}

\section{Position of Sovereign Wealth Fund in The Structure of Indonesian State Institutions}

Article 156 The Omnibus Law on Job Creation wants the establishment of a Sovereign Wealth Fund (SWF) which is an institution with special authority in the context of managing central government investment. SWF is an Indonesian legal entity established by the central government under the name of the Indonesia Investment Authority (Sidik, 2020). The realization of the implementation of the establishment of the Indonesia Investment Authority (IIA) was carried out by establishing Government Regulation No.74 of 2020 concerning Sovereign Wealth Fund, hereinafter referred to as GR-SWF. IIA is an Indonesian legal entity that carries out planning, supervision and control of Indonesian investment to increase and optimize long-term managed investment value to support sustainable development (Article 5). The IIA carries out the realization of its duties by establishing a head office in Jakarta and branch offices outside the City of Jakarta and the Indonesian Territory (Article 4). Based on Article 2 of the GR-SWF, IIA is a legal entity that is fully owned by the Indonesian government and is directly responsible to the President for carrying out its performance. Being a legal entity is the main requirement for the IIA to be a legal subject who has the power or authority to support rights and obligations. A legal entity as a social symptom is a real symptom as a fact in the relationship, even though it is not tangible (Imaniyati, 2009, p.124). Based on the theory of realism or organ theory, a legal entity is not abstract (fiction) and is not an unsubjected wealth, but a real organism, which is truly incarnated in the association of law, which can form its own will through the existing instruments, like administrators and members. The function of a legal entity is equated with a human function, so a legal entity is no different from a human being a legal subject (Dignam and Galanis, 2009).

The basic reason why IIA must be in the form of a legal entity is that it can be a legal subject that has the following characteristics (Asshiddiqie, 2006, 
p.71): 1). Entity assets separated from the assets of other legal subjects; 2). Have certain ideal goals that do not conflict with statutory regulations; 3 ). Have their interest in legal scope; and 4). Has an orderly management organization according to the prevailing laws and regulations and its internal regulations.

The four characteristics relate to the IIA's ability to be legally responsible (Rechts-bevoegheid). This accountability is needed to limit the position and role of the administrators of the institution. Management of a legal entity is not personally responsible for an engagement made under the name of the corporation (limited liability) (Harahap, 2009, p.81). This limited liability can be exceeded if the management takes management actions that exceed the authority he should have. This condition allows the management to take full responsibility for the losses suffered by the institution, this is known as Piercing The Corporate Veil Doctrine (Sulistiowati, 2013, p.97).

The establishment of the IIA was based on the power of state regulation as a form of the contractual relationship between the state and the investors who invest their funds (Dignam and Galanis, 2009, p.7). The establishment of the IIA was based on the power of state regulation as a form of the contractual relationship between the state and investors who invest their funds (Dignam and Galanis, 2009, p.7). According to concession theory, a corporation is a creation of the state aimed at benefiting the whole society. According to this theory, the rights and obligations of corporations are granted by the state. The implication of this is that although commercial activities are carried out, the establishment of a corporation and obtaining the status of a legal entity must be aimed at making the corporation prioritize the public interest rather than seeking profit alone (Avi-Yonah, 2005, p.767). The justification for policies to prioritize the public interest is the benefit or role of the corporation as an instrument of economic growth that is socially beneficial (Hurst, 1970, p.17-18). Because of that, the establishment of the IIA was carried out by the government as a justification for accelerating development that leads to increased economic growth.

Another fundamental question is determining whether the IIA is in the form of a public legal entity or a private legal entity. This determination is important because it will correlate with the form of the institution's accountability to the party that invests its funds in IIA. Regarding the determination of an institution categorized as a public legal entity or a private legal entity, there are no laws and regulations that explicitly provide an operational definition of this matter. Although Law Number 37 of 2008 concerning the Ombudsman of the Republic of Indonesia and Law No.25 of 
2009 concerning Public Services use the term public service delivery, it does not mean that institutions that provide public services are declared to be in the form of public legal entities. For example, PT.KAI (Persero) is one of the corporations appointed by the Public Service Law to provide public services in the railroad transportation sector (Elucidation of Article 5 paragraph (4)), but PT.KAI (Persero) is a corporation in the form of a private legal entity.

Referring to N.E. Algra (1983) And Soedikno Mertokusumo (2005) As a basis for determining an institution in the form of a private legal entity or public legal entity, are as follows:

a. In Public Legal Entity. Legal relations in the form of actions determined unilaterally, such unilateral actions by the subject as the ruler against the citizen or individual, the initiative to defend their rights or law enforcement by the authorities, the law is compelling.

b. In Private Legal Entity. The legal relationship is based on the principle of autonomy of the parties or subjects with equal positions, the subject between individuals or the authority/government can be the subject of the initiative to defend their rights by the parties themselves, the law is complementary/non-compelling, although some force it.

If simplified in tabular form, it can be seen as follows: If simplified in tabular form, it can be seen as follows:

Table 2

Table of Criteria for Classification of Public Legal

Entities and Private Legal Entities

\begin{tabular}{clll}
\hline No & \multicolumn{1}{c}{ Criteria } & \multicolumn{1}{c}{ Public Legal Entities } & \multicolumn{1}{c}{ Private Legal Entities } \\
\hline 1 & Subject/Party & Government/individual & Individual/individual-government \\
2 & Legal & Vertical/unilateral between & Autonomous/horizontal between \\
& Relationship & countries and individuals & individuals and individuals \\
3 & Nature of Norms & constrain & constrain/unconstrain \\
4 & Consequences & Public law field/scope & Private law field/scope \\
\hline
\end{tabular}

Source: N.E. Algra dan Soedikno Mertokusumo

Referring to table 2 above, it can be explained that:

1) IIA is an institution formed by the state and owned by the state because the initial capital for the establishment of the IIA comes from the state. The IIA's initial capital of IDR15 Trillion came from separated state assets 
(Government Regulation of the Republic of Indonesia No.73 of 2020 concerning Sovereign Wealth Fund Initial Capital). Regarding IIA capital, it is determined based on Article 3 paragraph (3) GR-SWF, is IDR75 Trillion which can come from state participation and other sources. The initial stage of establishment as initial capital was paid up as much as IDR15 Trillion, while the remaining IDR60 Trillion would be added gradually. IIA's equity participation originating from separated state assets is one of the characteristics that the institution is in the form of a private legal entity because corporate finance is separate from state finances (Pramono, 2007). The different thing that applies to the IIA is that the corporation is directly responsible to the president, not to investors who put their funds or to suppliers of capital.

2) Has an autonomous or horizontal legal relationship between IIA as a corporation and other corporations, both as investors and as corporations, that will get loan funds from IIA. This statement is emphasized in Article 7 paragraph (2) GR-SWF which states that IIA in carrying out its business activities can collaborate with investment partners, investment managers, SOEs, government agencies or institutions, and or other entities both domestically and overseas.

3) The nature of the norms or rules established and issued by the IIA only applies specifically to parties who cooperate or make business agreements with IIA, and do not generally apply to all people, so that their nature is a consensus between parties. Policies or regulations made by IIA management are applied internally to IIA institutions and other parties related to IIA (Article 30 GR-SWF). If there is a violation of these regulations, the settlement will be carried out internally, unless it causes a criminal act, the settlement will be carried out through a judicial institution.

4) IIA carries out activities in the field of private law, namely the management of investments that will be earmarked for the development or establishment of corporations to increase national economic growth. The IIA's functions and duties based on Article 7 paragraph (1) of the GR-SWF are as follows:

a) Placing funds in financial instruments;

b) Carrying out asset management activities;

c) Cooperating with other parties, including trust fund entities (trust fund); 
d) Determine potential investment partners;

e) Providing and receiving loans;

f) Administering assets;

g) The functions and tasks that are carried out are in the commercial or business sphere and not in the form of activities within the realm of public law.

Based on the description that refers to the four criteria, it can be explained that the IIA is in the form of a private legal entity.

IIA as an institution has a management organ consisting of a supervisory board and a board of directors. The supervisory board is appointed and dismissed by the president, which consists of (Article 166 Omnibus Law on Job Creation jo Article 9 GR-SWF):

1) The Minister of Finance as Chairman and concurrently as a member;

2) Minister of SOEs as a member; and

3) 3 people who come from professional elements as members, with a mass of 5 years and can be re-elected for one next term.

The form of the management organ, which consists of a board of supervisors and directors, is similar to that of a public company in SOEs (Law No. 19 of 2003 concerning State-Owned Enterprises). This also adds to the corroborating evidence that IIA is a private legal entity.

\section{Privilege Sovereign Wealth Fund}

There are several immunity rights possessed by IIA that are different from other institutions which seem superior to IIA. The features obtained by IIA are as follows:

1. IIA is formed by law and will only be dissolved by law (Article 171 Omnibus Law on Job Creation), and IIA is directly responsible to the President (Article 156 paragraph (3) Omnibus Law on Job Creation jo Article 2 GR-SWF). This provision has implications for the potential for abuse of power because the IIA has huge powers. The huge authority is not directly proportional to the supervision of the IIA. This form of financial supervision is not carried out by the Audit Board of the Republic of Indonesia but only audited by a public accountant (Article 161 Omnibus Law on Job Creation jo Article 52 paragraph (3) GR-SWF), 
which means that there is a looseness in the financial supervision system because the phrase "public accountant" releases the obligation of state auditors (Supreme Audit Agency) and the potential for fraud that leads to corrupt practices (Simabura: 2020). This condition certainly creates discrimination in treatment for SOEs that are also established by the state but their financial supervision is carried out by the Supreme Audit Agency and are vulnerable to demands for misuse of state finances.

2. IIA's initial capital was IDR 75 Trillion. According to finance minister Sri Mulyani, IIA's equity comes from the capital in cash worth IDR 30 Trillion, state-owned assets, state receivables, and state shares in SOEs. The cash injection is in the process of being discussed. The Omnibus law on Job Creation stated that IIA's initial capital was set at least IDR 15 Trillion in cash. It is hoped that IIA will be able to attract investment funds of up to 3 times the equity or amounting to the US $\$ 15$ billion or IDR 225 trillion (Rosana, 2020). In the corporate mechanism in the form of a private legal entity, government capital that is separated from the State Expenditure Budget is not part of state finances (Pramono, 2007), but a different practice is carried out on SOEs, which often means SOEs finance as state finance. The regulation regarding IIA finances is stated in Article 158 paragraph (4) of the Omnibus Law on Job Creation, "Profits or losses experienced by an institution in carrying out an investment are the advantages and disadvantages of the institution", the phrase "Profit and loss for the institution" means that the IIA's gains and losses are only calculated as a business risk is not calculated as part of the profit or loss of state finance. This is another form of discrimination that is also imposed on other state institutions such as SOEs.

3. State and SOEs assets can be transferred to IIA in the context of increasing IIA's capital (Article 55 GR-SWF). Another unique thing is that IIA assets can be guaranteed to obtain a loan (Article 160 paragraph (2) Omnibus Law on Job Creation jo Article 39 paragraph (3) GR-SWF). words that can be pledged to withdraw loans open up opportunities for the government to increase its debts. This means that state and SOEs assets transferred to IIA will become debt collateral to attract new debt, and this will certainly reduce the value of these state and SOEs assets. 
4. Article 160 paragraph (3) of the Omnibus Law on Job Creation states that any party is prohibited from confiscating IIA's assets, except for assets that have been pledged as collateral for a loan. If linked with Article 162 paragraph (1), which states that IIA organs and employees are not state administrators, except those from state officials who are $e x-$ officio in nature. The phrase "not state administrator" indicates an attempt to avoid investigating corruption crimes that require the status of state administrators. Further provisions in Article 163 "The minister of finance, officials of the ministry of finance, and organs and employees of the institution cannot be held liable for legal liability for investment losses if they can prove: .... etc". This provision gives immunity to the relevant officials and IIA management not to be prosecuted for allegedly causing losses to state finances. These three articles are correlated to Law No.31 of 1999 jo Law No.20 of 2001 concerning Corruption and Law No. 8 of 2010 on Prevention and Eradication of Money Laundering (PEML). Efforts to seize institutional assets based on these two laws are made possible by law enforcers, especially by the Corruption Eradication Commission, based on allegations of corruption, in which the suspect cannot be held accountable and explain the origin of his assets (Hamzah, 2020). The provisions which state that IIA's organs and employees are not state officials and prohibit the confiscation of assets against IIA is certainly a form of discrimination for other state institutions that can be enforced against the Corruption Act and the PEML Act.

5. IIA is not bankrupt. Based on Article 72 GR-SWF states that IIA cannot be bankrupt, unless it can be proven that IIA is in a condition of insolvency, the burden of proof is borne by the bankrupt applicant. If this provision is linked to Article 61 paragraph (6) GR-SWF which states if the accumulated losses of IIA cause IIA's capital to decrease to $50 \%$ of the initial capital, the government can increase IIA's capital. It means IIA will never be insolvent because the state will subsidize the funds for IIA. In simple terms it can be said that IIA will not possibly go bankrupt unless the country itself dissolves IIA.

6. The article of Sapu Jagat (one-size-fits-all) law is also enforced in regulations relating to the IIA. Article 164 paragraph (2) of the Omnibus Law on Job Creation states that as long as it is regulated in the work copyright omnibus law, the provisions of the laws and regulations governing the management of state finances, state assets and/or state- 
owned enterprises do not apply to IIA. This privilege for the IIA presents an opening for the creation of robbery of state finances.

The various privileges given to the IIA have created discrimination for other state institutions. This condition is not impossible to create demands on the state for preferential treatment for IIA, which has an impact on public distrust of the seriousness of the government to build the nation's economy.

\section{CONCLUSIONS}

The establishment of the IIA based on the Omnibus Law on Job Creation has legal issues ranging from the form of an entity that is only declared as a legal entity without explicit clarity into a private legal entity or a public legal entity. When referring to company capital that is separated from state finances and the scope of work of IIA which is engaged in business activities, it can be concluded that IIA is a private legal entity. Furthermore, if it looks at the organ of the institution which consists of the supervisory board and directors, it can be stated that this institution is similar to a Public Company as contained in the SOEs Law. The various privileges imposed on the IIA, ranging from only being established and dissolved by law to the enactment of the Sapu Jagat law rule, indicate that the government is discriminating against other state institutions, in particular, such as SOEs. The government should cancel the privileges and exemptions of the IIA because it opens up space for irregularities in state finances and demands unfair treatment by other state institutions.

\section{REFERENCES:}

\section{Books}

Alan Dignam dan Michael Galanis, (2009). The Globalization of Corporate Governance, Farnham: Ashgate Limited Publishing.

Bambang Sunggono, (2007). Metodologi Penelitian Hukum, Jakarta: Raja Grafindo Persada.

Bernard Arief Sidharta, (2001). Filsafat Ilmu Hukum, Bandung: Laboratorium Hukum Fakultas Hukum Universitas Khatolik Parahyangan.

Jimly Asshiddiqie, (2006). Perkembangan dan Konsolidasi Lembaga Negara Pasca Reformasi, Jakarta: Sekretariat Jendral dan Kepaniteraan Mahkamah Konstitusi RI. 
M. Yahya Harahap, (2009). Hukum Perseroan Terbatas, Jakarta: Sinar Grafika.

N.E. Algra, K. Van Duyvendijk, J.C.T. Simorangkir, and H.Boerhanoeddin Soetan Batoeah, (1983). Mula Hukum: Beberapa Bab Mengenai Hukum dan Ilmu untuk Pendidikan Hukum dalam Pengantar Ilmu Hukum, Jakarta: Binacipta.

Neni Sri Imaniyati, (2009). Hukum Bisnis: Telaah Tentang Pelaku dan Kegiatan Ekonomi, Yogyakarta: Graha Ilmu.

Soedikno Mertokusumo, (2005). Mengenal Hukum Suatu Pengantar, Yogyakarta: Liberty.

Soejono and H. Abdurrahman, (2003). Metode Penelitian Hukum, Jakarta: Rineka Cipta.

Soerjono Soekanto and Sri Mamudji, (2006). Penelitian Hukum Normatif, Jakarta: Rajawali.

Suistiowati, (2013). Tanggung Jawab Hukum Pada Perusahaan Grup di Indonesia, Jakarta: Erlangga.

\section{Book chapter}

Nindyo Pramono, 2007, Kekayaan Negara Yang Dipisahkan Menurut UU No 19 Tahun 2003 tentang BUMN, Dalam Permasalahan Seputar Hukum Bisnis: "Persembahan Kepada Sang Maha Guru", Gitama Jaya: Jakarta.

\section{Journal article}

Reuven S. Avi-Yonah, (2005). The Cyclical Transformation of the Corporate Form: A Historical Perspective on Corporate Social Responsibility, Delaware Journal of Corporate Law, Vol. 30, No.1.

\section{Website document}

Assegaf Hamzah, Omnibus Law 2020: Overview Series, Retrieved from https://www.ahp.id/ahp-omnibus-law-2020-overview-series\#title

Chandra Iswinarno dan Muhammad Fadil Djailani, Sovereign Wealth Fund, Anak Buah Menkeu Iri Dengan Khazanah Malaysia, Retrieved from 
https:/www.suara.com/bisnis/2020/12/02/153759/lembaga-pengelolainvestasi-anak-buah-menkeu-iri-dengan-khazanah-malaysia?page=all

Cantika Adinda Putri dan Herdaru P, Tok! DPR Sahkan RUU Omnibus Law Cipta Kerja Jokowi Jadi Undang-undang, Retrieved from https://www.cnbcindonesia.com/news/20201005143138-4-191978/tok-dprsahkan-ruu-omnibus-law-cipta-kerja-jokowi-jadi-uu

Charles Simabura, Tinjauan Ketatanegaraan Lembaga Investasi Pemerintah, disampaikan pada Konferensi Bedah Cluster Omnibus Law: Pendapat Para Ahli", 16 Oktober 2020.

Francisca Christy Rosana, 4 Fakta Soverign Wealth Fund yang Diharapkan Sri Mulyani Sedot IDR255 T, Retrieved from https://www.bisnis.tempo.co/amp/1393938/4-fakta-lembaga-pengelolainvestasi-yang-diharapkan-sri-mulyani-sedot-rp-255-t

Herdiansyah Hamzah, Investasi Pemerintah Pusat dan Kemudahan Proyek Strategis Nasional, disampaikan pada Konferensi Bedah Cluster Omnibus Law: Pendapat Para Ahli", 16 Oktober 2020.

Sekretaris Negara Republik Indonesia, Retrieved from https://www.setneg.go.id/view/index/undang_undang_republik_indone sia_nomor_11_tahun_2020_tentang_cipta_kerja

Sorta Tobing, 2020, Rupa Sovereign Wealth Fund Seperti Temasek Dalam UU Cipta Kerja, Retrieved from https://katadata.co.id/amp/sortatobing/finansial/5f7cbc5a0b289/rupalembaga-pengelola-investasi-seperti-temasek-dalam-uu-cipta-kerja

Sulaeman, Tak Ingin Ketinggalan dari Malaysia, Pemerintah Bentuk Soverign Wealth Fund, Retrieved from https://m.liputan6.com/bisnis/read/4423370/takingin-ketinggalan-dari-malaysia-pemerintah-bentuk-lembagapengelola-investasi

Syahrizal Sidik, 2020, Resmi SWF Bernama Indonesia Investment Authority, CNBC Indonesia, Retrieved from https://www.cnbcindonesia.com/market/20201218125410-17210031/resmi-swf-bernama-indonesia-investment-authority-ina-

Tom Allard, ed all, 2020, Indonesia Sovereign Wealth Fund Aims to Raise $\$ 15 b$ by Offering Multiple Funds, Retrieved from https://www.thejakartapost.com/amp/news/2020/11/17/indonesia- 
sovereign-wealth-fund-aims-to-raise-15b-by-offering-multiplefunds.html,

Vincent Lingga, Indonesia's Planned \$5b Sovereign Wealth Fund Raises Question, The Jakarta Post, Retrieved from https://www.thejakartapost.com/amp/academia/2020/10/26/indonesiasplanned-5b-sovereign-wealth-fund-raises-quistions.html,

Widodo S. Jusuf, Pemerintah akan Bentuk Soverign Wealth Fund, Retrieved from https://www.m.republika.co.id/amp/q5oti5383

About Temasek, Retrieved from https://www.temasek.com.sg/en/who-weare/about-us.

Sejarah Pusat Investasi Pemerintah Retrieved from https://umi.id/sejarah/

The Khazanah Report: Khazanah Nasional Berhad, Retrieved from https://www.khazanah.com.my/our-performance/the-khazanah-report/. 